\title{
Rethinking science for sustainable development: Reflexive interaction for a paradigm transformation
}

\author{
Andreas Kläy, Anne B. Zimmermann*, and Flurina Schneider \\ Centre for Development and Environment (CDE), University of Bern, Hallerstrasse 10, 3012 Bern, \\ Switzerland.
}

Corresponding author: anne.zimmermann@cde.unibe.ch (tel.: +41 3163152 73)

Accepted article, October 2014

\begin{abstract}
:
If we postulate a need for the transformation of society towards sustainable development, we also need to transform science and overcome the fact/value split that makes it impossible for science to be accountable to society. The orientation of this paradigm transformation in science has been under debate for four decades, generating important theoretical concepts, but they have had limited impact until now. This is due to a contradictory normative science policy framing that science has difficulties dealing with, not least of all because the dominant framing creates a lock-in. We postulate that in addition to introducing transdisciplinarity, science needs to strive for integration of the normative aspect of sustainable development at the meta-level. This requires a strategically managed niche within which scholars and practitioners from many different disciplines can engage in a long-term common learning process, in order to become a "thought collective" (Fleck) capable of initiating the paradigm transformation. Arguing with Piaget that "decentration" is essential to achieve normative orientation and coherence in a learning collective, we introduce a learning approach-Cohn's "Theme-Centred Interaction"-which provides a methodology for explicitly working with the objectivity and subjectivity of statements and positions in a "real-world" context, and for consciously integrating concerns of individuals in their interdependence with the world. This should enable a thought collective to address the epistemological and ethical barriers to science for sustainable development.
\end{abstract}

\section{Highlights:}

- Science needs to be transformed to become science for sustainable development

- Future transdisciplinarity must face the contradictory normative framing of science

- Pursuing one's concern rather than only facts or critiques can transform science

- Ruth Cohn's learning approach can lead to a transformative thought collective

- Science policy must provide a strategically managed niche for this innovation 


\section{Introduction}

The purpose of science and innovation policies, which are increasingly being formulated with a view to showing how science ${ }^{1}$ should be accountable to society (Frodeman \& Holbrook, 2011; Holbrook, 2012), is to help shape society's future. But accountable based on what values? For what kind of future? On the one hand, the declared aim of national research and innovation policies in the global North is generally to increase the international competitiveness of science in order to enhance each nation's competitiveness on the global market. We observe this normative framing in Switzerland-the authors' own national science policy context-where the government's education, research, and innovation funding policy "is based on an awareness of the fact that Switzerland can only maintain and further consolidate its very competitive and world-class position if it remains a knowledge-based society" (State Secratariat for Education, Research and Innovation 2014retrieved 25.02.2014). This also occurs in the European context, where the Horizon 2020 research programme was recently launched: the programme "promises more breakthroughs, discoveries and world-firsts by taking great ideas from the lab to the market. Horizon 2020 is the financial instrument implementing the Innovation Union, a Europe 2020 flagship initiative aimed at securing Europe's global competitiveness"(Horizon 2020 2014). However, since the 1970s an increasing number of science policy actors worldwide have been requiring that research and education lead to sustainable development and human wellbeing in the long term (Deutsche UNESCO-Kommission, 2012; Fuller \& Sardar, 2012; ICSU, 2014; IPCC 2013; ISSC 2012, p. 16; Jahn, 2013; Jantsch, 1972; Miller et al., 2014; ProClim/CASS 1997; Tàbara \& Chabay, 2013, p. 72; WBGU 1997; WBGU 2011; Williams \& Woodson, 2012, p. 222). This is a different, alternative normative framing of research: here the future that needs to be shaped is defined by the norms of human rights and sustainability, rather than by those of international competitiveness and economic growth.

While both normative framings invoke science as a means of innovation, what is considered as innovative is defined differently under the two framings. In the case of the dominant normative "competitiveness" framing, scientific results are expected to contribute to greater competitiveness of a country's economy and institutions (Frederiksen \& Beck, 2010, p. 136; Frodeman \& Holbrook, 2011b). By contrast, sustainability-oriented science policy considers research to be innovative if it supports the transformation towards more sustainable development.

Science for sustainable development is thus confronted with a fundamental contradiction arising from this double normative framing of science policy: can scientists really live up to their role of contributing to sustainable development, while at the same time helping societies achieve only greater economic growth, at the expense of equity and the environment? The answer is no, not really, as the starting point for science for sustainable development is a critique of the social and environmental impacts of the struggle for higher returns on investment among economic units competing on the global market (Jackson, 2011; P. Ulrich, 2008).

The two normative framings of science policy are generally related to different understandings of science. The dominant "competitiveness" framing is based on the norm of objectivity, which is often defined as value-free. This denial of the need to reflect on values in science has been amply critiqued as flawed, because it is based on a "fact/value split" (van Gigch, 2006, p. 5) that epistemological theory has

\footnotetext{
${ }^{1}$ In this article, science includes all academic disciplines that claim that their research and education activities (or knowledge production and reproduction activities) at universities and other research institutes need to be institutionally recognized and provided with funding. The norms that these disciplines need to live up to in order to be recognized by society and receive adequate funding, are regulated by science policy; these norms thus define disciplines' societal accountability.
} 
proven wrong ${ }^{2}$. This understanding of science postulates that science serves society best by providing "objective" knowledge that enters the market through competitiveness. Our position, on the contrary, is that accountability and value orientation are fundamental for science and require a transformation of the science paradigm and corresponding policies and institutions. Science for sustainable development has long sensed the need to address this issue but it has only just started to understand the magnitude of the problem and the crucial need to make values a core element of "sustainability science" (Miller et al., 2014see table p. 243).

Indeed, there are different understandings of what science for sustainable development should be (ISSC 2012; Kapoor, 2007; Uwe Schneidewind \& Singer-Brodowski, 2013, p. 227 ff; WBGU 2012). These differences are due to different understandings of the accountability of science and to the "ambiguous and controversial" meanings attributed to sustainable development (Wuelser, Pohl, \& Hirsch Hadorn, 2012, p. 81). ${ }^{3}$ How can we, as scientists who see a need for transformation, truly enable ourselves to contribute to science for sustainable development? First, we need to acknowledge that science always has a societally relevant value dimension. This is not a new claim but insights have not led to a change of practice in science policy and science. Only then will it be possible to adequately clarify the meanings of sustainable development, for example by engaging with a reflexive (Voss, Bauknecht, \& Kemp, 2006) and valueconscious form of transdisciplinary research (Giri, 2002).

Rather than addressing the issue of the value dimension of science once again at the theoretical level and trying to reply to questions such as "what should science for sustainable development be and what norms should it be guided by" in even greater detail, we would like to address the challenge from a pragmatic angle and deal with the question: "how can science for sustainable development be conducted and how can scientists be empowered to reach out from the margins of academic activities and influence scientific institutions at large?"

The question "how to do science for sustainable development" is not a new concern among scientists either. Over the past four decades a number of national and international research groups and institutions have been trying to address the issue, underlining the need for crossing disciplinary boundaries and addressing normative issues inherent in sustainable development (Dahle, 2007; Miller et al., 2008). A recurring answer has been to conduct "transdisciplinary" research (Hirsch Hadorn et al., 2008; Hurni \& Wiesmann, 2014; Jantsch, 1972; Nicolescu, 1996; Proclim/CASS 1997; Wiesmann, Hurni, Ott, \& Zingerli, 2011). In this context, scholars have tried to establish the theoretical and conceptual foundations of transdisciplinarity (Brandt et al., 2013; Pohl, 2014) , leading to numerous different understandings of the new kind of research needed for enabling science to address its societal responsibility, sometimes also under other names [e.g. mode 2 research (Nowotny, Scott, \& Gibbons, 2001), post-normal science (Funtowicz \& Ravetz, 1993), and futures studies (Ziauddin Sardar, 2009)]. As mentioned above, it is not our aim here to contribute to this conceptual level of the debate. A number of scholars have also refined methods for implementing transdisciplinary and other forms of transformative research (Colucci-Gray, Camino, Barbiero, \& Gray, 2006; Klein, 2004; Lange, 2004, 2012; Lawrence \& Després, 2004, pp. 398-399; Miller et al., 2014; Pohl, 2011). However, these efforts have often been marginalized by academic institutions, which do not have a clear common understanding of sustainable development and transdisciplinary research, and therefore lack criteria for quality control for such new research (Jahn, 2013, p. 30; Wuelser et al., 2012, p. 81). This, in turn, leads to a systematic discrimination of papers and proposals

\footnotetext{
${ }^{2}$ Hilary Putnam argues that the "fact/value dichotomy" leads to the dogma "that facts are objective and values are subjective" ((Putnam, 2002, p. 145), p. 145); he then claims that this contradicts the epistemological insight that "'valuation' and 'description' are interdependent-a possibility that is constantly overlooked by positivists and their ilk" (p. 62).

${ }^{3}$ One example of a vague understanding of sustainability can be found in (Schensul, 2009), p. 249. He focuses on the "sustainability of interventions", defining it as the sustained effects on participants and organizations; see also p. 252.
} 
apt at contributing to innovation of science towards sustainable development (Bridle, Vrieling, Cardillo, Araya, \& Hinojosa, 2013, p. 24), "as such an approach [i.e. journal ranking] generates a rather narrow and idiosyncratic view of excellence" (Rafols, Leydesdorff, O'Hare, Nightingale, \& Stirling, 2012, p. 1280).

We believe that what is needed is a paradigm transformation ${ }^{4}$ in the very conception (and institutionalization) of science as a human activity. This requires a much stronger community of scientistswhich we conceive of as a Fleckian "thought collective" - willing to address the normative and epistemological issues involved in "doing science" as a conscious member of society in an increasingly complex world in need of more sustainable development. The present paper proposes a very concrete way of making a first step towards inducing this paradigm transformation, which we perceive as a colossal, but crucial and fundamentally enlightened, ${ }^{5}$ epistemological and social challenge. Indeed, scientists should not only produce knowledge for transformation (i.e. a product) but also conceive of science as transformative research (i.e. as a process) (U Schneidewind \& Jahn, 2012; van Egmond \& de Vries, 2011; WBGU, 2011). In order to get there, it is necessary, first, to organize a learning process within science.

In order to propose a feasible way of integrating the transdisciplinary practice and ethical positioning needed in science to move towards "science for sustainable development" in a concrete science policy context, we began by providing an explanatory framework for the question "how to conduct transformative science." In the following sections, we further elaborate this framework, based, first, on a discussion of where science stands with regard to transformation (Section 2) and second, on the need for "strategic niche management" (Geels, 2011; Nill \& Kemp, 2009), to enable concerned scientists to conduct the proposed epistemological and ethical inquiry (Section 3). Third, we postulate the need for establishing a learning collective that will be able to eventually develop into a "thought collective" (Fleck, 1979), and we introduce Jean Piaget's (1931) vision of "international education" as a means of creating "reflexive coordination" within this learning collective (Section 4). Fourth, and this is where we become very concrete, we link this explanatory framework with a learning approach that comes from psychology and was developed by Ruth Cohn, using "Sardar's laws of futures studies" (Ziauddin Sardar, 2010, pp. pp. 182184) as benchmark, in order to position the present article in the debate that is taking place in Futures. ${ }^{6}$ Cohn's group learning approach-entitled Theme-Centred Interaction (Cohn, 2002)-has the aim of sharpening individuals' ability to perceive the implications of their actions and consciously make decisions about them, by helping them to enhance their capacity to see both within and outside themselves and take into account normative reflections (Section 5). Fifth, we suggest what themes for transformation should be considered by the learning collective (Section 6). The final sections broaden the perspective once again and discuss our proposal within the context of other reflections on transdisciplinary practice (Sections 7 and 8 ).

As mentioned initially, our proposition is based on three decades of experience at a university centre in Switzerland whose mission is to engage in research, teaching, and support for policy and practice in the field of sustainable development. Our activities are conducted with partners in Switzerland and in

\footnotetext{
${ }^{4}$ We have chosen to avoid the concept of "paradigm change", as it is strongly associated with Thomas S. Kuhn's argument about the "structure of scientific revolutions"(see .(Kuhn, 1979)) Indeed, what we envision is not a revolutionary but a transformative process based on reflection. We find Brorson and Andersen's ((Brorson \& Andersen, 2001)) description of the differences between Kuhn and Ludwik Fleck illuminating: “Contrary to Kuhn's account, Fleck's account [of the genesis and development of scientific facts] emphasizes the non-revolutionary change of the phenomenal world, which he claims is due to a continuous flux of thoughts and ideas. For Fleck the phenomenal world is never a fixed world, but is continuously reshaped through circulation within and between the social strata and their literature. It is through this circulation that statements become proved, facts become verified and thoughts become objects of reality" (p. 123).

${ }^{5}$ Our proposal is rooted in the historical humanist project of transforming society (Kant), and taps on some of the related ongoing debates (e.g. C.W. Churchman, W. Ulrich, J. Habermas, H. Putnam).

${ }^{6}$ In its Guide for Authors, Futures encourages authors to read Ziauddin Sardar's article entitled "The namesake"; we are grateful for this briefing, as it helped us to understand the history of the journal and enabled us to position our argument in relation to Sardar's four "laws of futures studies" ((Ziauddin Sardar, 2010), p. 182). Indeed, these four laws provide a very balanced orientation for a comprehensive understanding of science in the world; our proposition is very much in line with this orientation.
} 
developing countries. In our work, we have repeatedly been led to reflect on how to relate different forms of knowledge with one another and how to increase the societal reach of our research. This is why we have engaged in the debate on transdisciplinarity and social learning (Fry, Zingerli, Kläy, \& Förster, 2011; Gabathuler, Bachmann, \& Kläy, 2011; Pohl et al., 2010; Rist, Chidambaranathan, Escobar, Wiesmann, \& Zimmermann, 2007; F. Schneider, Ledermann, Fry, \& Rist, 2010; Flurina Schneider \& Rist, 2013; Wiesmann et al., 2011; Zingerli et al., 2009).

\section{The need for change has been identified, but where is transformation?}

In Switzerland, research and tertiary education follow international standards and have so far shown only a marginal potential for innovation for sustainable development (Akademien der Wissenschaften Schweiz, 2010). There have been several attempts over the past decades to help research for sustainable development make a breakthrough, with some remarkable initiatives. ${ }^{7}$ However, these initiatives have often been marginalized by the dominant framing of science policy, which does not explicitly integrate a reflection on the normative dimension of science in society within research activities and outputs (Kläy, 2012). At the European and North American levels, proposals and programmes exist for transforming science to meet the challenges of sustainable development (Knowledge Learning and Societal Change Alliance, 2012; Miller et al., 2014; RESPONDER, 2014; VISION RD4SD). Nonetheless, the impact of these initiatives has also remained minimal to date-they remain niches. The pervasive disciplinary fragmentation of science, the absence of a reflection on norms in research policy, and the lack of political commitment constitute major constraints for the transformation of science: "At present, the production of scientific and technological knowledge tends to occur without adequate reference or 'sustainability validation' regarding the social-ecological contexts" (Tàbara \& Chabay, 2013, p. 72). Therefore, academic efforts aiming for change lack integrative scientific performance, political foundations, and financial means (Hessels \& van Lente, 2008, p. 758). Most attempts remain dominated by disciplinary approaches, or oriented towards singular thematic aspects and individual methodological propositions such as transdisciplinarity, given that they need to find institutional legitimation within the dominant science system (Padmanabhan, 2012).

Among the remarkable exceptions are those based on institutional decisions recently made by strong leaders who succeeded in making available the means and midterm orientation for founding new institutes. In Germany, Leuphana University Lüneburg and the Wuppertal Institute for Climate,

Environment, and Energy are very good examples (U Schneidewind \& Jahn, 2012) - numerous others could be added from other countries as well, such as Edith Cowan University in Australia (Wooltorton, Palmer, \& Steele, 2011), and Schumacher College in England (Sterling, 2011). With the creation of dedicated centres, institutes, and study programmes, the transformation towards science for sustainable development has definitely started. However, as long as these initiatives have not been legitimated by a broader science and science policy community on their own terms instead of according to a norm that excludes their validity $a$ priori, they will not be used as references by the dominant system and therefore will not succeed in gaining the status of a "dominant policy narrative" (Leach, Scoones, \& Stirling, 2010, pp. 130-132). Indeed, reaching the status of a dominant (or mainstream) narrative is what would enable them to induce transformation, which they would do because they actually submit themselves to a "sustainability validation" (Tàbara \&

\footnotetext{
${ }^{7}$ Among the initiatives are the "Schwerpunktprogramm Umwelt (SPPU) des Schweizerischen Nationalfonds", the "Visions by Swiss Researchers: Research on Sustainability and Global Change" (Proclim/CASS, 1997), the foundation by SAGUF of the Network for Transdisciplinary Research (td-net) and td-net's integration into the Swiss Academies of Science, and the National Centre of Competence (NCCR) North-South programme.
} 
Chabay, 2013, p. 72). A sustainability validation is what is needed to make science different from what it has generally been until now.

In addition to these explicit science policy initiatives for sustainable development, a large conceptual potential exists for the transformation of science in individual contributions coming from various disciplines such as critical sociology (Beck, 1992; Bourdieu, 2004), gender research (Haraway, 1991), critical anthropology (Clifford \& Marcus, 1986), development studies (Freire, 1973), integrative economic ethics (P. Ulrich, 2008), capabilities approach (Nussbaum, 2011; Sen, 2009), sociological (Latour, 2004; Wetzel, 2012) and educational (Lange, 2012) reflections on the Enlightenment, critical systems thinking (Churchman, 1979; Flood \& Romm, 1996; Werner Ulrich, 2012ab; 2012ba), and many others. This list is far from complete. None of these contributions is clearly oriented towards a sustainability validation of science, although all could actually contribute to such a validation. Ideally, in order to tease out the performative power of these critical contributions and offer a new, coherent framework for defining transformative science for sustainable development, it would be necessary to explore and integrate the potential of these contributions. Such an integration can only be achieved by a "thought collective", as we will argue in the next section.

\section{The need for "strategic niche management" and a new "thought collective"}

With a view to specifying the starting point for our decision to propose a pragmatic process as a first step to initiate the paradigm transformation needed for science for sustainable development, we would like to come back to the dilemma of small niches of change existing, but without the power to reach the status of a dominant narrative and induce a comprehensive transformation. These niches therefore remain in a deadlock or "lock-in". The concept of lock-in is used in the context of sustainable innovation policies (Geels, 2011; Loorbach \& Rotmans, 2010; Markard, Raven, \& Truffer, 2012); Nill and Kemp, among others, propose that "strategic niche management" (2009, p. 674) is needed to overcome the "barriers to technological regime shifts offering sustainability benefits" (2009, p. 670). In their view this lock-in of technological transformation is caused by regimes based on neoclassical economics. The lock-in of science transformation that we consider is created by the prevailing paradigm of science policy regimes and landscapes, as pointed out by proponents of transdisciplinary research, e.g. in Switzerland (Akademien der Wissenschaften Schweiz, 2010). Edgar Morin describes the dilemma related to this lock-in from the perspective of education for sustainable development: "one cannot reform institutions before reforming people's minds, but one cannot reform their minds before reforming institutions" (Morin, 2011, p. 162). ${ }^{8}$

How can one deal with such a dilemma? There is no way out since it is a dilemma, so it is necessary to find a way to walk the tightrope. One possibility, as proposed by the above-mentioned sustainability transition scholars in the context of innovation and management studies, is to create niches that are "a source for transformative ideas and capabilities, but not blueprints" (Smith, Voß, \& Grin, 2010, pp. 440441). We argue that such niches are also necessary for the transformation of science; how can the existing niches be empowered for this new work? We think that they need to be managed in such a way that within them, members of various disciplines meet with the aim of transforming science to make it more appropriate for contributing to sustainable development. Although this may seem very familiar to proponents of transdisciplinary research - with other concepts such as "agora" (Nowotny et al., 2001) and "transactional spaces" (Gibbons, 1998)-there is a difference. Indeed, the purpose of the strategic and pragmatic niche management that we propose is not to focus on specific real-world problems (Hirsch

\footnotetext{
${ }^{8}$ Our translation of the French original: "on ne peut pas réformer l'institution sans avoir au préalable réformé les esprits, mais on ne peut pas réformer les esprits si l'on n'a pas au préalable réformé les institutions" (Morin 2011: 151).
} 
Hadorn et al., 2008), as is the case in most sustainability research agendas (see for example Reid et al., 2010), but to engage with a meta-level concern and conduct a profound common inquiry into the scientific inquiry system itself (Latour, 2004; van Gigch, 2006) and into its (in)ability to address the double normative framing which is the crux of this paper. ${ }^{9}$

In order to be able to conduct this meta-level inquiry within the strategically managed niche, members of various disciplines need to become a "thought collective" with their own "thought style" (Fleck, 1979). ${ }^{10}$ Indeed, for each of these diverse members, the process of understanding is shaped by a specific epistemological structure (Pohl, 2011), which we will call "disciplinary" here to simplify matters. The niche is there to help members acknowledge their epistemological differences and develop a common epistemological basis ("thought style") without losing their individual (disciplinary) identity. At the same time, in a common learning process, they need to be able to focus on the normative dimension of sustainable development at the science policy level. How can they do this?

\section{Steps towards developing a value-oriented and self-reflexive thought collective for engaging with a redefinition of science}

Enabling members of very different disciplines to engage in a process of exchange on how science could become sustainability-oriented is a major challenge. In the strategic niche management for science transformation proposed above, there is a need for understanding how every individual can encounter the radically different others in the group, and how everyone can remain him- or herself while at the same time understanding the other and making progress with them towards a common understanding of value orientation in science. ${ }^{11}$ Psychology and adult education deliver interesting insights into the processes involved and steps needed. In our view, Jean Piaget and Ruth Cohn provide an ideal combination of the concepts needed to understand and facilitate value-conscious individual and group learning processes. Indeed, both are explicitly rooted in an Enlightenment vision of practical reason and autonomy, which are key to the project of transforming the paradigm of science towards greater sustainability.

\subsection{The role of decentration}

We believe that Piaget's description of the psychological and epistemological process of "decentration" (Piaget, 1950) is extremely useful to understand what kind of reflexive activity is required of individuals engaging in crossing epistemological boundaries. Indeed, Piaget's understanding of the process is based on a theory of intellectual evolution which shows the interdependence of the individual, the others, reality out there, and the norms that regulate our interaction: understanding cannot be gained from an entirely selfcentred perspective. ${ }^{12}$ In his psychological vision of international education, Piaget argues:

\footnotetext{
${ }^{9}$ This does not mean that real-world problems should not be addressed by research for sustainable development, on the contrary: the paradigm transformation that we claim is needed, and for which we suggest a pragmatic approach, will make it more possible to conduct such research and provide a more adequate framing for it.

10 'If we define 'thought collectives' as a community of persons mutually exchanging ideas or maintaining intellectual interaction, we will find by implication that it also provides the special 'carrier' for the historical development of any field of thought, as well as for the given stock of knowledge and level of culture. This we have designated thought style" (p. 39; italics in the original). For Fleck, participation in a long-term research process is what leads to the emergence of a thought collective, which is thus the result a common learning process.

${ }^{11}$ This minimal common understanding of value orientation is a fundamental requirement for being able to share the common concern for moving towards transformation of the science paradigm. For another (philosophical) perspective on what kind of communication is needed to cross disciplinary borders, see for example Holbrook's differentiation between three different conceptions of interdisciplinary communication and the corresponding impacts these conceptions have on theorizing such communication (Holbrook, 2013).

12 "To decenter means to "group", and thanks to the reciprocities obtained by stepping out of the necessarily deforming and egocentric perspective that is our point of departure, real connections and operative reversibility are established in a correlative way. This is why intellectual progress is neither just linear nor just cumulative: it is simultaneously constructive and reflexive
} 
All that is needed is to create in each person a method of understanding and reciprocity. Everyone should learn how to situate him- or herself among the whole of all other human beings, without stepping out of their own perspective and without trying to eliminate their beliefs and feelings, which is what makes them humans with flesh and blood, connected with a clearly delimited and living part of the universe. Everyone should thus stick to their own perspective as the only one that they know from inside, but should also understand the existence of the other perspectives; in particular, everyone should understand that truth, in all things, cannot be encountered as a given: it is something that is painstakingly elaborated thanks to the coordination of these perspectives. (Piaget, 1931, p. 64) 13 $^{13}$

Decentration in the strategically managed niche is a way forward for developing the thought collective and enabling its members to consciously perceive their individual epistemological boundaries and constitute a new thought style, as well as develop a clear ethical orientation.

\subsection{Creating a learning collective: a prerequisite for a new kind of thought collective}

What are the obstacles in such an individual and joint learning process? They are many and inherent to human interaction in general; they cover a broad range of aspects, from power to identity formation, emotion, cognition, language, ethics, etc. In essence, before the group of individuals can tackle Morin's dilemma and really develop into a thought collective, what needs to happen is for this group to first become a learning collective; part of their work will be to "unlearn", for which great "humility, modesty and accountability" are required (Ziauddin Sardar, 2009, p. 444). It is crucial to underline that participation in the learning collective has to be based entirely on participants' fundamental concern about the relation between science and sustainable development. This common concern is what will help them overcome the initial disorientation resulting from the diversity of perspectives, the lack of a systematic normative debate in science, and the double normative framing in science policy.

The members of the learning collective need, first, to have a common will to address the meta-level issue of science for sustainable development. Second, none of the members should desire to develop and master an approach that excludes the diversity of views represented by the other members of the learning collective. This is particularly difficult because as academics, we are trained (we could also say disciplined) to be disciplinary and to organize our thinking in a convincing and competitive way. The members must therefore be willing to unlearn their disciplinary privileges, ${ }^{14}$ i.e. they must be willing to temporarily divest themselves of their academic habits and the power that goes with these habits. Third, in order for the

because it is due to a double move of external integration [= integration of external relations] and internal coordination [of virtual operations of the subject on the object]" (translation by the authors of the present article, with support from Jean-Jacques Ducret). Original text: Décentrer signifie "grouper», et c'est grâce aux réciprocités atteintes en sortant du point de vue nécessairement déformant et égocentrique de départ que s'élaborent corrélativement les connexions réelles et la réversibilité opératoire. C'est pourquoi le progrès intellectuel n'est ni simplement linéaire ni simplement cumulatif, mais simultanément constructif et réflexif parce que dû à un double mouvement d'intégration externe et de coordination interne. (Piaget, 1950, p. 112). The Introduction à l'épistémologie génétique is Piaget's attempt to write a genealogy of (Western) scientific knowledge based on a genealogy of epistemologies, which is itself based on a theory of psychological development.

${ }^{13}$ Translation by the authors of the present article, with support from Jean-Jacques Ducret. Original text: /l ne s'agit que de créer en chacun une méthode de compréhension et de réciprocité. Que chacun, sans sortir de son point de vue, et sans chercher à supprimer ses croyances et ses sentiments, qui font de lui un homme en chair et en os, attaché à une portion bien délimitée et bien vivante de l'univers, apprenne à se situer parmi l'ensemble des autres hommes. Que chacun tienne ainsi à sa perspective propre, comme à la seule qu'il connaisse de l'intérieur, mais comprenne l'existence des autres perspectives; que chacun comprenne surtout que la vérité, en toutes choses, ne se rencontre jamais toute faite, mais s'élabore péniblement, grâce à la coordination même de ces perspectives. The subtitle of the book in which Piaget's lecture was published translates as "how to promote awareness of the League of Nations and develop a spirit of international cooperation." In 1931, after World War I the Western world tried to develop a global governance body to avoid falling back into mechanisms that would lead to a further globalized war. The League of Nations was replaced after World War II by the United Nations, a governance body within which sustainable development efforts have been, and continue to be, globally negotiated.

${ }^{14}$ Here we borrow a very enlightening expression that comes from subaltern studies (see Spivak, 1988). 
learning collective to become a thought collective capable of initiating a paradigm transformation, sufficient time must be made available to its members for them to be able to work in this manner; for example, a buy-out system must be developed.

\subsection{Facilitating the learning process}

Our experience with Theme-Centred Interaction or TCI (Cohn, 2002; Cohn \& Farau, 2001) provided evidence that $\mathrm{TCl}$ is a particularly adequate approach for enabling the learning collective to function, as its key tenet is value orientation (Box 1). Indeed, $\mathrm{TCl}$ is designed to enable group members to a) acknowledge their diversity, b) be guided by a common concern, $c$ ) be willing to build an atmosphere of respect by temporarily abandoning disciplinary competitiveness, and d) be willing to work over a longer period of time together in order to develop into a thought collective.

$\mathrm{TCl}$ is a well-known approach in professional training for social work and organizational development. It is a proven means of integrative learning in situations where gaps between world views and values seem unbridgeable, mainly because of power relations (Stollberg, 2008). Unfortunately, it is hardly known in science concerned with building bridges across disciplinary and other epistemological boundaries, including in the context of sustainable development. The appropriateness of the approach is rooted in the core aim of $\mathrm{TCl}$, which is to enable individuals to increase their ability to take responsibility for themselves in their interdependence with others and with nature. Thus, as we argue in greater detail in Section 7, the appropriateness of the approach for our proposal is also probably the reason why Cohn's work has not been reflected upon to date in research concerned with sustainable development. Indeed, since the dominant norm in science (objectivity) is that facts and values ought to be split (van Gigch, 2006, p. 5) and researchers should only focus on establishing facts in their work, not on relating their work to values, it is only normal that reflections on interdisciplinarity and transdisciplinarity within the context of this science system cannot be open to an approach such as Cohn's.

\section{Box 1: Experience with $\mathrm{TCl}$ in the fields of "natural resource management" and "humanism and power"}

While elaborating a conceptual framework for sustainable management of natural resources in 1995, the Centre for Development and Environment (CDE) saw the need for developing a concrete way of enabling those concerned to relate local knowledge with scientific knowledge (Centre for Development and Environment, 1998). A concept enabling intense knowledge exchange between local resource users and trained staff and researchers was developed based on existing actionresearch approaches and extension methods. However, the numerous approaches, methods, and tools available at the time in the field of development cooperation and development research did not offer a pragmatic approach to mutual integration of value-consciousness. By contrast, $\mathrm{TCl}$ offered clear foundations for the design and moderation of workshops that we called "Learning for Sustainability" (Gabathuler et al., 2011). Experience with a number of these three-week workshops over the years demonstrated the appropriateness of Cohn's approach to enable individuals in a group to practice "living learning" (Wortel \& Bosch, 2011, p. $23 \mathrm{ff}$ ) and the first author of the present paper engaged in participation in several TCl projects from 2002 to increase his TCl competence. One project was particularly ambitious and revealing. It focused on the question: "How do I handle power within the polarity of humanist axioms and Zeitgeist". The project offered a heterogeneous and gender-balanced (and therefore large) group a learning and reflection experience during 6 three-day sessions that took place over a time span of more than 2 years. The theme is of high relevance to learning for sustainable development, as it foregrounds individual decision-making and action based on a moral orientation in a societal context characterized by a Zeitgeist of "anything goes if you are competitive". The strength of the $\mathrm{TCl}$ approach in relation to this specific topic triggered reflection about its potential appropriateness for the science and science policy issues dealt with in the present paper. 


\section{An interaction approach to empower scientists as agents of change}

We now turn to a concise presentation of Ruth Cohn's Theme-Centred Interaction (TCl) approach. When Cohn started developing her approach to group learning, she began by conceptualizing $\mathrm{TCl}$ as a means for enabling individuals in a group to acquire the necessary capabilities to contribute to an overall vision of humanity living in freedom and peace ${ }^{15}$. Her first name for TCI was WILL, or "the WILL approach". WILL stood for "Workshop Institute for Living-Learning" (see also Wortel \& Bosch, 2011). The double meaning was intended. Cohn defined WILL as "a decision between 'I would like to' (I feel like), 'I must' (inevitable compulsion or necessity), 'I am supposed to' (a rule dissociated from the self), and 'I should' (a value accepted by the self)"; the German "Ich will" ("I want") "is the conscious, integrated answer to "I would like to, I must, I am supposed to, I should"' (Cohn \& Farau, 2001, p. 345; translation by the authors).

However, is Ruth Cohn's "will" really sufficient for such an intellectual venture as the one we describe in this paper? Sardar's third law-the duty to be sceptical-needs to be applied here (Ziauddin Sardar, 2010, p. 183). Can TCl stand the litmus test of complexity? Is it an appropriate group learning approach to deal with the wicked problem-Sardar's first law (Ziauddin Sardar, 2010, p. 183)-of designing a procedure for developing a science paradigm compatible with sustainable development? In the following, we present and scrutinize the concept of $\mathrm{TCl}$-however without discussing the whole philosophical, ethical, and psychological background of $\mathrm{TCl}$ that was developed in the context of psychological and philosophical studies.

\subsection{Compatibility with future transdisciplinarity}

Cohn applied TCl before naming it; she used it with therapists working in supervision groups. Experience showed that it was also possible for other people to apply $\mathrm{TCl}$ coming from any other profession, provided they were trained in the method and its application. This is how the new "profession" of TCl group moderation arose. As Cohn explained, "apart from ensuring the necessary training of therapists, social workers, politicians, religious leaders, and university and school teachers, it is important for me to train people who do not belong to a specific professional group, such as parents, young people, committee members, members of a local residential community or union, etc." (Cohn \& Farau, 2001, p. 345). This is very close to a declared aim in one of the more common definitions of transdisciplinarity, which is to bring stakeholders from science and society together (Elzinga, 2008; Hurni, Wiesmann, \& with an international group of co-editors, 2010).

The ultimate goal of $\mathrm{TCl}$ is an ethical one: to realize progress in the pedagogic-therapeutic struggle against Inhumanity, which is perceived to be due to simplifications in people's minds about what humanity should look like. $\mathrm{TCl}$ aims to help participants take into account the complete diversity of humanity without negating their unique individuality. The $\mathrm{TCl}$ approach allows understanding the interdependency and the autonomous potential to (inter-)act responsibly, and thus to live together in small groups such as families, teams, communities, groups of friends, colleagues, peers, as well as in larger social groups such as social classes and ethnic groups, races, nations, cultures, and in our planetary community. This satisfies Sardar's (2010, p. 183) second law, "mutually assured diversity". This understanding of interdependence involves that learning participants need to develop knowledge about interrelations and are capable of decentering

\footnotetext{
${ }^{15}$ At this stage, Ruth Cohn was not completely satisfied with her activity as therapist. Her life was marked by the experience that a whole nation can lose its orientation towards human dignity: she was born in a Jewish family in Berlin and moved to Switzerland for her studies; she lost many friends and members of her family in the Holocaust and realized that this was because of a "lack of education" among her contemporaries. Therefore she felt that in addition to therapy, there was a need for enhancing people's autonomy by education. She therefore conceptualized her experience in group supervision and workshop moderation, developing $\mathrm{TCl}$ as a result. Her aim was to enable everybody to learn to say "I" comprehensively (Cohn 2002).
} 
themselves-and therefore of envisaging moral progress (Piaget, 1931). Ruth Cohn's TCl is structured in such a way that it enables this developmental process.

\subsection{Ruth Cohn's Theme-Centred Interaction approach (TCI)}

$\mathrm{TCl}$ is based on a clear and simple, but demanding, methodological framework: a model containing three axioms, two postulates, and a method/structure (Cohn \& Farau, 2001, pp. 351-374). The concept is grounded in the tradition of the Enlightenment and human rights. It requires that participants interact in a way based on reflective individual autonomy, as described in the axioms. The concept of TCl makes it possible to explicitly work with the polarity between objective statements and theories on the one hand, and subjective statements and positions in a real-world context on the other. TCl enables individuals (in our case scientists inquiring into the meta-level of science for sustainable development) to both reflect on the science system and be part of it in a transformative way.

\section{Three axioms:}

"1) The human being is a psycho-biological unity and a part of the universe. For that reason he or she is autonomous and interdependent at the same time. An individual's autonomy becomes greater, the more our consciousness of everyone's interdependence with everything can be extended." (Cohn, 2002, p. 74; italics in the original)

Note: autonomy is defined via the individual's conscious ability to relate to others, and not as a matter of power.

"2) Reverence is due to everything living and to its growth. Respect for growth necessitates value judgements in making decisions. The humane is valuable, the inhumane is threatening to values." (p. 74)

Note: this axiom considers nature as a whole (of which humans are a part) to be a value, in addition to human dignity.

“3) Free will occurs within conditional internal and outer boundaries; expansion of these boundaries is possible." (p. 75)

Note: this potential expansion of one's horizon is what makes it possible for a paradigm transformation to ultimately grow out of a learning collective's interaction.

\section{Two postulates:}

"First postulate: Be your own chairperson.

That means:

a) Be aware of yourself and of your internal realities and your environment.

b) Take each situation as an opportunity to make your own decision. Give and take according to how you wish to be responsible for yourself and other." (p. 76)

"Second postulate: Disturbances and strong involvements have precedence." (p. 77)

Note: The reason for giving disturbances precedence is that they always have important impacts; if we do not acknowledge this, the impacts become more pernicious. Disturbances also have a potential for increasing awareness. 


\section{A method/structure:}

The TCl method structures the dynamics of group interaction into four factors (Figure 1):

- The person (the I), conscious of subjective feelings and perceptions;

- The interaction of the group (the We); the "We" is not a psycho-biological organism like the "I" but a shape (Gestalt) developed by the interaction between the individual participants.

- The theme or the task (the It or Theme). The Theme is a small part or aspect of the world on which the group is focussing.

- The environment in the narrow sense and largest sense (the GLOBE). "With this designation I intended from the very beginning to include not only the neighbouring context in room and time, but the entire area of exterior influences." (p. 72)

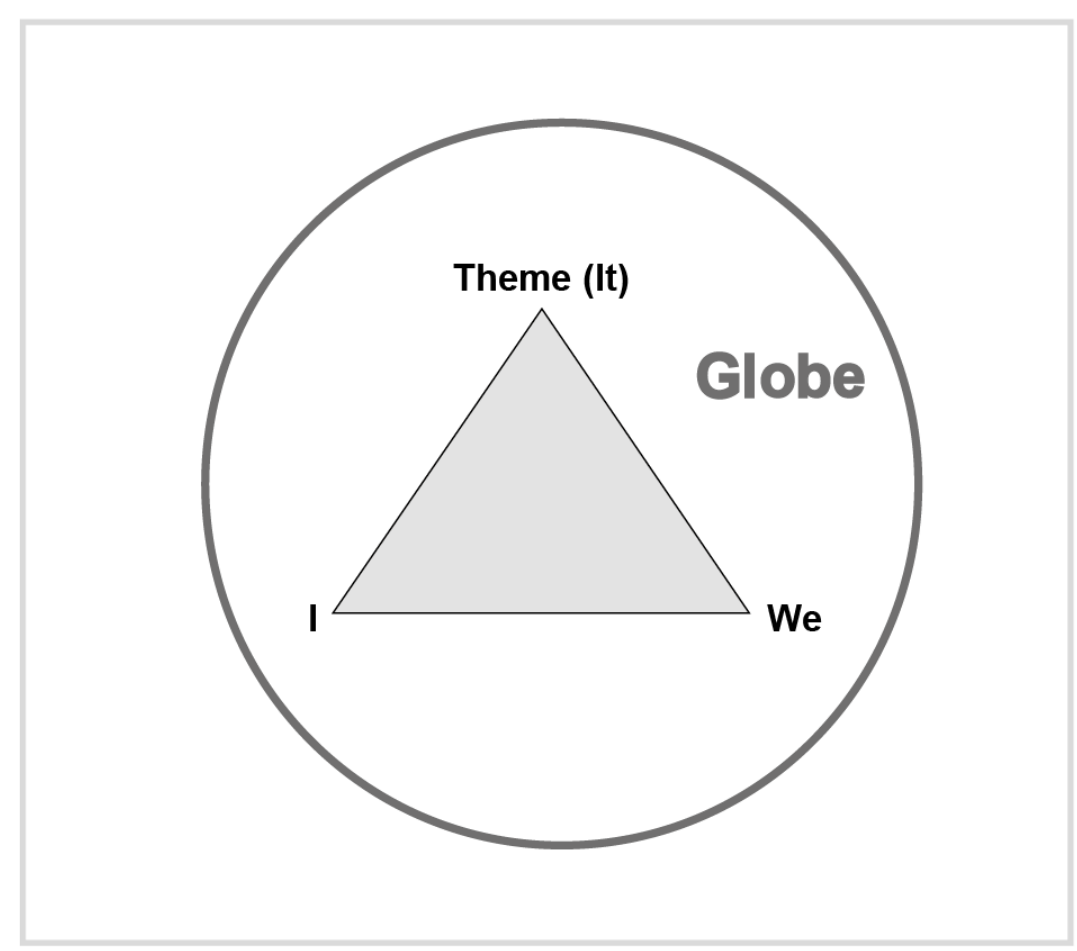

Figure 1: Ruth Cohn's four factors in Theme-Centred Interaction (TCI); based on (Cohn, 2002; Cohn \& Farau, $2001, p$. $352 \mathrm{ff})$.

The $\mathrm{TCl}$ group learning process consists of a balancing between these four factors; the balance is never stable and always has to be re-established, relying on every participant's will to be his or her own chairperson (first postulate) and the group's willingness to deal productively with disturbances (second postulate). "The fundamentals of group leadership according to the method of TCl was defined with this hypothesis of balance between the elements I, WE, IT, and GLOBE. ... In schools, universities and other educational institutions, the IT is emphasised at the expense of the I and WE. ... Being conscious of the dynamic balance in group leading is just as easy to express theoretically, as it is difficult to practice" (Cohn, 2002, p. 73). Indeed, science is far away from such a balance, as it often tries to strictly distinguish between objective facts on the one hand and subjective statements and positions in a "real-world" context on the other (Putnam, 2002, p. 145). The result is a split between facts and values, and a consequential loss of normative orientation in science. 


\section{Themes for inquiry for the learning collective}

Strategic niche management aiming for greater sustainability orientation in science will have to ensure that the learning collective (and future thought collective) can address the fundamental problem of the fact/value dichotomy. The learning collective should not shy away from focusing on the key difficulty that researchers who address sustainability need to deal with the dominance of disciplinary structures and the dogma of objectivity (Putnam, 2002, p. 145) in the work that they need to conduct (Morin's dilemma). Relating disciplinary knowledge to world views and corresponding science policy framings will be a key theme to be taken up by the learning collective. In fact, some of this work has already started: we repeatedly hear the call for a systems approach (social-ecological systems, Earth system, ecosystems, etc.) within the community dealing with research for sustainable development. Indeed, there are many points of juncture between visions of transdisciplinarity, futures studies, and systems approaches. Looking back, the earliest milestones were Jantsch and Churchman.

In the 1970s, Jantsch explicitly referred to a systems approach when he developed his concept of transdisciplinarity: "Inter and transdisciplinarity thus become the key notions for a systems approach to education and innovation" (Jantsch, 1972, pp. 107, italics in the original). The principal function he ascribed to transdisciplinarity was the "co-ordination of all disciplines and interdisciplines in the education/innovation system [...]" (p. 106). Such coordination cannot take place without a normative orientation, otherwise it does not lead to Sardar's "mutually assured diversity", nor does it focus on sustainable development. Jantsch perceived this and expressed it in the following proposal: "The normative level, with planning as its 'organisational language', deals with social systems design, bringing into focus social systems or ecological technology in its broadest sense. It has as its core Churchman's 'ethics of whole systems' and branches out into aspects of social systems technology, such as law, macro-economics, and institutional innovation" (Jantsch, 1972, p. 109, italics in the original).

In his 1979 book entitled The Systems Approach and its Enemies, C. West Churchman offered a very stimulating reflection that is another milestone in the abundantly burgeoning field of systems sciences (Ramage \& Shipp, 2009). He defined the fact-value split as an attempt to deal with the incommensurable complexity of real-world problems. Churchman, a philosopher at the Berkeley School of Management, was dissatisfied with the way in which the natural and social sciences claimed that neither of the two could deal properly with the complexity of the Earth system. Instead of trying to decide who was right, he requested that a reflection begin at a meta-level on the epistemological requirements of science, which in his view, included a consideration of values - a key concern in his view. Instead of trying to deal only with facts and only with looking for solutions to problems, he asked a far more useful question: "How can we design improvement without understanding the whole system?" (Churchman, 1968, p. 3). Churchman also recognized what he called the "environmental fallacy" (Churchman, 1979, pp. 4-5), which is a result of science addressing mainly the identification and the solution of problems, and not the systemic and related ethical aspects.

There is much to learn from these milestones and from the debates that have followed. There are certainly other lessons that need to be taken into account as well. The learning collective will also have its own, multiple sources of insights, arising from the many disciplinary perspectives that have already developed a thorough critique of the limitations of disciplines with regard to their ability to be transformative, and of the science policy conditions that provide the normative framing within which science for sustainable development can (not) take place. A crucial task of the learning collective will be to define the thematic basis with which they will engage, and to learn together how to address the relevant value orientation and power issues. 


\section{Discussion}

This paper started off by pointing out the need for enabling science to support the transformation towards sustainable development. The dominant normative framing of science policy does not make it possible for science to live up to the norm of sustainable development that is now being increasingly supported by proponents of transdisciplinary research. Although we are gaining insight into how systems work, critical systems thinking has shown that this will never be enough to make human behaviour change: we are faced "with the impossible cognitive requirements of an empirical-predictive future discourse and with difficult ethical conflicts between the interests of future and present generations" (Werner Ulrich, 1994, p. 36). Indeed, within the context of the climate change debate, renowned scientists recently recognized the need to clearly issue a call for action (Hansen et al., 2013, p. 20). However, the authors' remarkable scientific effort to provide decision-makers with soundly established facts, motivated explicitly by a moral position, is concluded by a clear statement that their "objective is to define what the science indicates is needed, not to assess political feasibility" (p. 21). Is this a tenable position for science for sustainable development? Miller, Wiek et al (2014, p. 240) argue that "sustainability scientists [should not be] just generators of knowledge but also knowledge brokers and change agents". In order to act as agents of change, scientists must reflect on the impact of their work [see Sardar's fourth law: "future studies are futureless [...] The law forces us to focus on the consequences of the discourse on the present and the immediate future" (Ziauddin Sardar, 2010, p. 184)]. How can science become more transformative, given the fundamental lock-in within which it is caught, which is revealed by the fact that two radically different positions can be taken with regard to the scientist's role in society?

We have argued that science needs to be enabled to engage with values in a more fundamental way than perceived as possible by Hansen and co-authors; indeed, the limitation that they set up is based on the dominant normative framing of science policy. As long as this framing remains the only basis for the dominant regime, the impact of existing individual disciplines and dedicated centres aiming for sustainable development will remain marginal. They contribute to a diversity that is not assured (Ziauddin Sardar, 2010, p. 183, second law). What is needed is a larger community capable of inducing a change in framing; we have used the Fleckian concept of thought collective to refer to this larger community. We have also argued that such a collective can only emerge if a learning collective is given the opportunity to tackle the challenge of integrating values at the meta-level of rethinking science for sustainable development. How can this transformative learning be enabled?

There is a need for an interaction approach of the kind described by Lange (2004): she claims a need to adopt transformative and restorative learning rather than taking the path of transformation theory. Indeed, her research has led her to the insight that it is "not disruption but the restoration of the participant's foundational ethics to a conscious place in their daily lives" that will enable them to "withstand the disorienting aspects of transformation and remain open to threatening new knowledge" (Lange, 2004, p. 135). We have argued that individuals in the learning collective need to "unlearn their disciplinary privileges". They can only do that in a safe space in which transformative and restorative learning are possible. We would like to add that such learning is transformative and not revolutionary, and as such less likely to lead to backlash; in this sense, it is in line with Fleck's understanding of the development of insights.

\subsection{Acknowledging diversity and building a respectful learning community}

$\mathrm{TCl}$ can enable a comprehensive process combining transformative and restorative learning among participants, making it possible for them to argue, and at the same time reflect on, normative aspects, and 
not stop at a boundary predefined by disciplinary methods, conventions, or career needs. ${ }^{16}$ They are in a safe space within which they can also afford-and indeed are required to-abandon "strategic action" in favour of "communicative action" (Habermas, 1981) and welcome emotions and concerns that are not normally considered part of intellectual activity. ${ }^{17}$ Research on education for sustainable development has shown how important this is for the success of a learning and transformative process (Lange, 2004, 2012; Ziauddin Sardar, 2009; Sterling, 2011; van Egmond \& de Vries, 2011).

In a TCI process, determining the limitations of the safe learning space is always the responsibility of each and all participants. In doing this, they will follow another principle defined by Cohn (2002, p. 77), "selective authenticity". The balance of interactions respects the four factors (I, We, Theme, Globe) and therefore "not everything has to be said, but what is said, should be genuine" (Cohn, 2002, p. 77). All participants have the responsibility to contribute to and enhance the learning of the group (chairperson postulate). Interaction based on $\mathrm{TCl}$ makes it possible to reduce the hindrances normally imposed by formal and informal conventions and enables participants to develop a discourse favourable to formulating ethical aspects. Thus, freedom of interaction is increased and participants are able to reflect on and relate to contributions such as those formulated by critical science (sociology, psychology, gender studies, social anthropology, geography, science studies, etc.).

Another relevant comment made by Ruth Cohn is that the three axioms and two postulates are the principles that will prevent misuse of TCI "as a self-negating technology" (Cohn, 2002, p. 74 ff.). ${ }^{18}$ In the context of increasing critiques of the "post"-type which tend to lead their proponents to a standstill with regard to their original transformative intention, $\mathrm{TCl}$ is a particularly appropriate approach to prevent a group of intellectuals from slipping into negative reflexivity, which is the kind of activity that Bruno Latour describes as leading critique to "run out of steam" (Latour, 2004).

Comparing it with concepts discussed in the debate on transformative education, the similarity with Freire's "pedagogy of the oppressed" springs to mind. As argued by Lange, roots of transformative learning can be found in the Enlightenment. "However, a rational-thinking process is necessary and vital for human thinking, whether to debate the weaknesses of theories themselves ... or to discern ethical implications, analyse ideologies, and recognize the limits of human agency and rationalism themselves" (Lange, 2012, p. 8). ${ }^{19}$ However, despite the very convincing reflection offered by Lange on transformative and restorative learning, Cohn's interaction approach is more adequate in our view for the objectives we have in mind, for the following reasons:

1. The simplicity of Cohn's method makes its application compelling, provided one takes the trouble of continuously revisiting it to capture the meaning of the simply-stated axioms and postulates.

2. With her second axiom, Cohn includes nature in the value orientation in her learning concept. This is not done by Lange, nor by Freire, whose pedagogy of the oppressed Lange comments on in a very illuminating way (Lange, 2012). Indeed, Lange (and Freire's) focus is human dignity; they do not mention nature as an equally important value. In our view this is an essential addition in the equation when it comes to sustainable development (by contrast with adult education or pedagogy of agency).

\footnotetext{
${ }^{16}$ See also Putnam's clear conclusion about the fact/value dichotomy: "The worst thing about the fact/value dichotomy is that in practice it functions as a discussion-stopper, and not just a discussion-stopper, but a thought-stopper" (Putnam 2002, p. 44)

${ }^{17}$ The meaning of strategic in "strategic niche management" is not the same as in Habermas' "strategic action": in the first case, the aim of strategic niche management is to consciously create a niche, a protected space for interaction and learning, where participants are not forced to follow the dominant rules and criteria of scientific work leading to a fatal interruption of discussion and thought (Putnam 2002, p. 44), competition, and fragmentation. Strategic niche management is explicitly an attempt to deal with the regime for the purpose of emancipation from the regime.

${ }^{18}$ Cohn's biography made her extremely conscious of the dangers of "group think" and she formulated her concept in such a way that it provides what is needed to avoid such dangerous slippings.

${ }^{19}$ In this sense, Lange proposes a way to deal with the difficulties stated by Ulrich in the quotation at the beginning of Section 7.
} 
3. In addition, the combination of the first axiom (autonomy and interdependence) with the first postulate (be your own chairperson), makes it possible for the learning collective to enable each autonomous individual to contribute to the mutual learning process. Within a context in which power and position are so fundamental, this part of the method is particularly potent.

Thus, we contend that $\mathrm{TCl}$ enables a learning collective to tackle the following key difficulties: taking into account multiple perspectives, acknowledging diversity and self-responsibility, and securing the validity of diversity through the ethical dimension. The learning collective's insights and competence will thus transform the former stumbling blocks into stepping stones for science for sustainable development (Kläy, 2012).

\subsection{A common concern: ensuring that science can become transformative science}

Using W.B. Yeats' powerful post-World War I metaphor of the falcon losing its bearings because it can no longer hear the falconer, Van Egmond and de Vries (2011) argue that there is a need for an integral worldview with a value in the centre attracting and thus counterbalancing the forces driving the diverse worldviews out of the centre of human dignity and "Mutually Assured Diversity" (Ziauddin Sardar, 2010). As announced early on in this paper, we do not aim to give this centre any further shape than the second (ethical) axiom of $\mathrm{TCl}$, "Reverence is due to everything living and to its growth". We limit ourselves to proposing how a group of intellectuals who wish to make science more transformative, in order to be able to better deal with the double normative framing mentioned initially, can be enabled to mutually develop this shape and maintain their original concern as an orientation.

In describing the "It" or "Theme", Cohn argues that the choice of theme must be determined by the group through an assessment of its relation to reality and values (Cohn \& Farau, 2001, p. 354). In other words, the Theme must embody their concern and at the same time relate to the second (ethical) axiom. In the same text, she reflects on what kind of theme has this quality-in our view clearly describing sustainability problems without, however, naming them as such: "themes that show reverence for life... are themes that include both general humanistic values and the needs of a group, and not themes that build their houses on the corpses of another part of the Earth or the Future" (Cohn \& Farau, 2001, p. 354). Paradoxically, the often-cited "problem-orientation" in research for sustainable development seems to lead to the latter thematic focus rather than to the former type, although the original intention of such research is to orient itself towards the former (this is Churchman's "environmental fallacy"). What is it that makes things go wrong? Lawrence and Desprès explain that "Transdisciplinary contributions frequently deal with real-world topics and generate knowledge that not only addresses societal problems but also contributes to their solution" (Lawrence \& Després, 2004, p. 399). Nonetheless, they also underline that this is applied knowledge and that a further step needs to be made: "there is no inherent reason why theoretical development-especially the analytical description and interpretation of complex environmental questions - cannot be achieved by transdisciplinarity. We argue that this is a basic necessity if advances are to be made in this vast and complex field of research" (Lawrence \& Després, 2004, pp. 399-400).

We would like to add a crucial point to their argument, since theoretical development has been initiated many times in the past ten years (or more) by a number of scholars but it still has not led to transformative science capable of dealing with Morin's dilemma. Transdisciplinarity's theoretical development cannot succeed if it does not maintain the concern that motivates researchers to start working on sustainability issues in the first place. This original concern is easy to lose in an academic world in which-to use Piaget's concept-we lose our ability to decenter ourselves and to be guided by our concern. Instead, we transform our concern into a "matter of facts" (Latour, 2004) and limit our scientific 
effort to the analysis of these facts, i.e. the problem, then offering solutions which may even increase the unsustainability of development (Churchman's "environmental fallacy").

\section{Conclusion}

There is an acknowledged need for establishing science for sustainable development. The signs we read from the literature of the past forty years show that this change has not yet taken place. Indeed, the dilemma has remained the same: it is not possible to initiate a change in science before people's minds have changed, and it is not possible to initiate a change in people's minds before science (as an institution) has changed. This is why we need nothing more than a paradigm transformation. Such a fundamental transformation needs to be initiated by a desired change among individuals capable of reflecting as a transdisciplinary group on the requirements for, and consequences of, integrating the normative dimension of sustainable development into research and education.

This is an impossible task for an individual, and even for a group. Much more is needed to transform the mission from a Sisyphus task to a successful step. First, at the institutional level, a strategically managed niche needs to be established for the work of the transdisciplinary group, and the success of their work should not be measured only by the number of peer-reviewed publications but by new criteria that the group will develop. Second, this group needs to perceive itself as a learning collective and be prepared to address the question of how science can live up to the expectation of having a transformative role in development. Third, to enable this group to go through the necessary learning, we suggest that Cohn's interaction approach be used. Fourth, the learning collective must continue to be supported by a strategic niche management until it can initiate transformation out of the niche. Perhaps this will ultimately enable a sufficiently large community to be able to do the work called for by Sardar:

The discourse we need must clarify what ethical principles we are accountable to, which must be upheld in the choices we make, with all the humility and modesty we apply to our understanding of our problems, searching for solutions with all the uncertainties, and hence risks and imperfections, we accept as routine elements in our affairs. (Ziauddin Sardar, 2009, p. 443)

Thus, our proposal goes a step further than what Jahn calls for in his essay entitled "Sustainability science requires a critical orientation" (Jahn, 2013). In our view, the orientation that transformative science needs cannot be found in critique alone: as Latour has polemically but rightly argued, critique has "run out of steam" (Latour, 2004). What we need is a critical mind that cultivates "a realism with what [he calls] matters of concern, not matters of fact" (p. 231). The legitimate critic for Latour is "not the one who debunks, but the one who assembles. The critic is not the one who lifts the rugs from under the feet of the naïve believers, but the one who offers the participants arenas in which to gather" (p. 246). In this article, we have not offered an arena, but we certainly hope to have offered a method for interacting productively and respectfully with others once the arena is there

\section{Acknowledgements}

The authors acknowledge support from the Education for Sustainable Development Cluster at the Centre for Development and Environment (CDE), University of Bern. They are also grateful to three anonymous reviewers for insightful comments that greatly contributed to improving this article. 


\section{References}

Akademien der Wissenschaften Schweiz. (2010). Nachhaltige Entwicklung: Thesen zu Nachhaltiger Entwicklung in Lehre und Forschung an universitären Hochschulen der Schweiz. Bern.

Beck, U. (1992). Risk Society: Towards a New Modernity. New Delhi: Sage.

Bourdieu, P. (2004). Science of Science and Reflexivity. Chicago, IL: University of Chicago Press.

Brandt, P., Ernst, A., Gralla, F., Luederitz, C., Lang, D. J., Newig, J., . . von Wehrden, H. (2013). A review of transdisciplinary research in sustainability science. Ecological Economics, 92, 1-15. doi: http://dx.doi.org/10.1016/j.ecolecon.2013.04.008

Bridle, H., Vrieling, A., Cardillo, M., Araya, Y., \& Hinojosa, L. (2013). Preparing for an interdisciplinary future: A perspective from early-career researchers. Futures, 53, 22-32. doi: http://dx.doi.org/10.1016/j.futures.2013.09.003

Brorson, S., \& Andersen, H. (2001). Stabilizing and changing phenomenal worlds: Ludwik Fleck and Thomas Kuhn on scientific literature. Journal for General Philosophy of Science, 32.

Centre for Development and Environment. (1998). Autodidactic Learning for Sustainability. A Concept for Autodidactic Training in Sustainable Use of Natural Resources for Development Personnel. University of Bern. Bern.

Churchman, C. W. (1968). Challenge to Reason. New York, NY: McGraw-Hill.

Churchman, C. W. (1979). The Systems Approach and Its Enemies. New York, NY: Basic Books.

Clifford, J., \& Marcus, G. E. (Eds.). (1986). Writing Culture: The Poetics and Politics of Ethnography. Oakland, CA: University of California Press.

Cohn, R. C. (2002). Living learning: a reader in theme-centered interaction. Delhi: Media House

Cohn, R. C., \& Farau, A. (2001). Gelebte Geschichte der Psychotherapie. Zwei Perspektiven. Stuttgart, Germany: Klett-Cotta.

Colucci-Gray, L., Camino, E., Barbiero, G., \& Gray, D. (2006). From scientific literacy to sustainability literacy: An ecological framework for education. Science Education, 90(2), 227-252. doi: DOI $10.1002 /$ sce. 20109

Dahle, K. (2007). When do transformative initiatives really transform? A typology of different paths for transition to a sustainable society. Futures, 39, 487-504. doi: doi:10.1016/j.futures.2006.10.007

Deutsche UNESCO-Kommission. (2012). Wissenschaft für Nachhaltigkeit: Der Durchbruch muss gelingen. Bonn, Germany: Deutsche UNESCO-Kommission e.V. Retrieved from

http://unesco.de/fileadmin/medien/Dokumente/Bibliothek/broschuere_memorandum_wissensch aft_fuer_nachhaltigkeit.pdf.

Elzinga, A. (2008). Participation. In G. Hirsch Hadorn, H. Hoffmann-Riem, S. Biber-Klemm, W. Grossenbacher-Mansuy, D. Joye, C. Pohl, U. Wiesmann \& E. Zemp (Eds.), Handbook of Transdiscilinary Research (pp. 345-360). New York: Springer.

Fleck, L. (1979). Genesis and development of a scientific fact. Chicago, IL Univ. of Chicago Press.

Flood, R. L., \& Romm, N. R. A. (Eds.). (1996). Critical Systems Thinking: Current Research and Practice. New York, NY, and London, United Kingdom: Plenum Press.

Frederiksen, L. F., \& Beck, S. (2010). Caught in the crossfire: educational research in context. International Journal of Research \& Method in Education, 33(2), 135-149. doi: http://dx.doi.org/10.1080/1743727X.2010.484620

Freire, P. (1973). Education for critical consciousness. New York, NY: Seabury Press.

Frodeman, R., \& Holbrook, J. B. (2011). NSF's struggle to articulate relevance. Science, 333(6039), 157-158. doi: doi: 10.1126/science.333.6039.157

Fry, P., Zingerli, C., Kläy, A., \& Förster, R. (2011). How to manage knowledge sharing: experiences from research practice. GAIA - Ecological Perspectives for Science and Society, 20(2), 130-132(133).

Fuller, T., \& Sardar, Z. (2012). Editorial for publication. Futures, 44, 845-846.

Funtowicz, S., \& Ravetz, J. (1993). Science for the Post-Normal Age. Futures 25, 739-755.

Gabathuler, E., Bachmann, F., \& Kläy, A. (2011). Reshaping Rural Extension. Weikersheim: Margraf.

Geels, F. W. (2011). The multi-level perspective on sustainability transitions: Responses to seven criticisms. Environmental Innovation and Societal Transitions, 1(1), 24-40. doi:

http://dx.doi.org/10.1016/j.eist.2011.02.002

Gibbons, M. (1998). Higher Education Relevance in the 21st Century. Washington, DC.

Giri, A. K. (2002). The calling of a creative transdisciplinarity. Futures, 34(1), 103-115. doi: 10.1016/S00163287(01)00038-6

Habermas, J. (1981). Theorie des kommunikativen Handelns. Frankfurt a.M., Germany: Suhrkamp

Hansen, J., Kharecha, P., Sato, M., Masson-Delmotte, V., Ackerman, F., Beerling, D. J., . . . Zachos, J. C. (2013). Assessing "Dangerous Climate Change": Required Reduction of Carbon Emissions to Protect 
Young People, Future Generations and Nature. PLOS ONE, 8(12), 1-26. doi: 10.1371/journal.pone.0081648

Haraway, D. J. (1991). A Cyborg Manifesto: Science, Technology, and Socialist-Feminism in the Late Twentieth Century Simians, Cyborgs and Women: The Reinvention of Nature (pp. 149-181). New York: Routldege.

Hessels, L., \& van Lente, H. (2008). Re-thinking new knowledge production: A literature review and research agenda. Research Policy 37, 740-760.

Hirsch Hadorn, G., Hoffmann-Riem, H., Biber-Klemm, S., Grossenbacher-Mansuy, W., Joye, D., Pohl, C., . . . Zemp, E. (Eds.). (2008). Handbook of Transdisciplinary Research. New York: Springer.

Holbrook, J. B. (2012). Re-assessing the science-society relation: The case of the US National Science Foundation's broader impacts merit review criterion (1997-2011). UNT Digital Library, 1-22. Retrieved from http://digital.library.unt.edu/ark:/67531/metadc77119/

Holbrook, J. B. (2013). What is interdisciplinary communication? Reflections on the very idea of disciplinary integration. Synthese, 190(11), 1865-1879. doi: 10.1007/s11229-012-0179-7

Horizon 2020. (2014). What is Horizon 2020? Retrieved 28.7.2014, 2014, from http://ec.europa.eu/programmes/horizon2020/en/what-horizon-2020

Hurni, H., \& Wiesmann, U. (2014). Transdisciplinarity in practice: Experience from a concept-based research programme addressing global change and sustainable development. GAIA - Ecological Perspectives for Science and Society, 23(3), 275 -277. doi: http://dx.doi.org/10.14512/gaia.23.3.15

Hurni, H., Wiesmann, U., \& with an international group of co-editors (Eds.). (2010). Global Change and Sustainable Development: A Synthesis of Regional Experiences from Research Partnerships (Vol. 5). Bern, Switzerland: Geographica Bernensia.

ICSU. (2014). Future Earth Retrieved April 01 2014, 2014, from http://www.icsu.org/future-earth

IPCC. (2013). Summary for Policymakers. In T. Stocker, D. Qin, G. Plattner, M. Tignor, S. K. Allen, J. Boschung, A. Nauels, Y. Xia, V. Bex \& P. Midgley (Eds.), Climate Change 2013: The Physical Science Basis. Contribution of Working Group I to the Fifth Assessment Report of the Intergovernmental Panel on Climate Change (pp. SPM-1-SPM-36). Cambridge, United Kingdom and New York, NY: Cambridge University Press.

ISSC (Ed.). (2012). Transformative Cornerstones of Social Science Research for Global Change. Paris: International Social Science Council (ISSC).

Jackson, T. (2011). Prosperity without growth: Economics for a finite planet. London: Routledge.

Jahn, T. (2013). Wissenschaft für eine nachhaltige Entwicklung braucht eine kritische Orientierung. Sustainability Science Requires a Critical Orientation. GAIA - Ecological Perspectives for Science and Society, 22(1), 29-33.

Jantsch, E. (1972). Towards interdisciplinarity and transdisciplinarity in education and innovation. In Centre for Educational Research and Innovation (CERI) \& Organisation for Economic Co-operation and Development (OECD) (Eds.), Interdisciplinarity: Problems of Teaching and Research in Universities (pp. 97-121). Paris, France: OECD.

Kapoor, R. (2007). Introduction. Transforming self and society: Plural paths to human emancipation. Futures, 39, 475-486. doi: doi:10.1016/j.futures.2006.10.001

Kläy, A. (2012). Nachhaltige Entwicklung an Schweizer Hochschulen: Zeit für Tritt- statt Stolpersteine. GAIA Ecological Perspectives for Science and Society, 21(4), 321-323.

Klein, J. T. (2004). Prospects for transdisciplinarity. Futures, 36(4), 515-526. doi: DOI 10.1016/j.futures.2003.10.007

Knowledge Learning and Societal Change Alliance. (2012). Transitioning to a sustainable future through knowledge and learning from www.ihdp.unu.edu/article/read/klsc

Kuhn, T. S. (1979). The structure of scientific revolutions. Chicago, IL: The University of Chicago Press.

Lange, E. A. (2004). Transformative and restorative learning: A vital dialectic for sustainable societies. Adult Education Quarterly, 54(2), 121-139. doi: Doi 10.1177/0741713603260276

Lange, E. A. (2012). Is Freirean Transformative Learning the Trojan Horse of Globalization and Enemy of Sustainability Education? A Response to C. A. Bowers. Journal of Transformative Education, 10(1), 3-21. doi: DOI: $10.1177 / 1541344612453880$

Latour, B. (2004). Why Has Critique Run out of Steam? From Matters of Fact to Matters of Concern. Critical Inquiry, 30(2), 225-248. doi: DOI: 10.1086/421123

Lawrence, R. J., \& Després, C. (2004). Introduction. Futures of Transdisciplinarity. Futures, 36(4), 397-405. doi: http://dx.doi.org/10.1016/j.futures.2003.10.005

Leach, M., Scoones, I., \& Stirling, A. (2010). Dynamic Sustainabilities - Technology, Environment, Social Justice. London, UK: Earthscan. 
Loorbach, D., \& Rotmans, J. (2010). The practice of transition management: Examples and lessons from four distinct cases. Futures, 42, 237-246. doi: 10.1016/j.futures.2009.11.009

Markard, J., Raven, R., \& Truffer, B. (2012). Sustainability transitions: An emerging field of research and its prospects. Research Policy, 41, 955-967. doi: doi:10.1016/j.respol.2012.02.013

Miller, T. R., Baird, T. D., Littlefield, C. M., Kofinas, G., Chapin III, F. S., \& Redman, C. L. (2008). Synthesis. Epistemological Pluralism: Reorganizing Interdisciplinary Research. Ecology and Society, 13(2), 46.

Miller, T. R., Wiek, A., Ansong, D., Robinson, J., Olsson, L., Kriebel, D., \& Loorbach, D. (2014). The future of sustainability science: a solutions-oriented research agenda. Sustainable Science, $9(239-246)$. doi: 10.1007/s11625-013-0224-6

Morin, E. (2011). La Voie. Pour l'avenir de l'humanité. Paris, France: Fayard.

Nicolescu, B. (1996). La Transdisciplinarité. Manifeste. Monaco: Editions du rocher.

Nill, J., \& Kemp, R. (2009). Evolutionary approaches for sustainable innovation policies: From niche to paradigm? Research Policy, 38(4), 668-680. doi: http://dx.doi.org/10.1016/j.respol.2009.01.011

Nowotny, H., Scott, P., \& Gibbons, M. (2001). Re-Thinking Science: Knowledge and the Public in an Age of Uncertainty. Cambridge, UK: Polity.

Nussbaum, M. C. (2011). Creating capabilities : the human development approach. Cambridge, Mass.: Belknap Press of Harvard University Press.

Padmanabhan, M. (2012). Transdisciplinarity for Sustainability. Demand and Challenge. GAIA - Ecological Perspectives for Science and Society, 21(1), 76-77.

Piaget, J. (1931). Introduction psychologique à l'éducation internationale Quatrième cours pour le personnel enseignant (pp. 56-68). Genève: Bureau International D'Éducation.

Piaget, J. (1950). Introduction à l'épistémologie génétique (Vol. 2, La pensée physique). Paris, France: Presses universitaires de France (PUF).

Pohl, C. (2011). What is progress in transdisciplinary research? Futures, 43, 618-626. doi: doi:10.1016/j.futures.2011.03.001

Pohl, C. (2014). A Theory of Transdisciplinary Research for Whom? Eine Theorie transdisziplinärer Forschung für wen? GAIA - Ecological Perspectives for Science and Society, 23(3), 216-220. doi: 10.14512/gaia.23.3.3

Pohl, C., Rist, S., Zimmermann, A., Fry, P., Gurung, G. S., Schneider, F., . . Wiesmann, U. (2010). Researchers' roles in knowledge co-production: experience from sustainability research in Kenya, Switzerland, Bolivia and Nepal Science and Public Policy, 37(4), 267-281. doi: doi: 10.3152/030234210X496628

Proclim/CASS Forum for Climate and Global Change/Conference of the Swiss Scientific Academies. (1997). Visions by Swiss Researchers: Research on Sustainability and Global Change -- Visions in Science Policy by Swiss Researchers. Bern, Switzerland: ProClim-, Forum für Klima und Global Change, and Schweizerische Akademie der Naturwissenschaften SANW.

Putnam, H. (2002). The Collapse of the Fact-Value Dichotomy and Other Essays. Cambridge, MA, and London, United Kingdom: Harvard University Press.

Rafols, I., Leydesdorff, L., O'Hare, A., Nightingale, P., \& Stirling, A. (2012). How journal rankings can suppress interdisciplinary research: A comparison between Innovation Studies and Business \& Management. Research Policy, 41, 1262- 1282. doi: doi:10.1016/j.respol.2012.03.015

Ramage, M., \& Shipp, K. (2009). Systems Thinkers. London, United Kingdom: Springer in association with The Open University, Milton Keynes, United Kingdom.

Reid, W., Chen, D., Goldfarb, L., Hackmann, H., Lee, Y., Mokhele, K., ... Whyte, A. (2010). Earth system science for global sustainability: Grand challenges. Science 330(60006), 916-917.

RESPONDER. (2014). Welcome to RESPONDER! , from www.scp-responder.eu

Rist, S., Chidambaranathan, M., Escobar, C., Wiesmann, U., \& Zimmermann, A. (2007). Moving from sustainable management to sustainable governance of natural resources: The role of social learning processes in rural India, Bolivia and Mali. Journal of Rural Studies, 23(1), 23-37. doi: http://dx.doi.org/10.1016/j.jrurstud.2006.02.006

Sardar, Z. (2009). Welcome to the postnormal times. Futures, 42, 435-444. doi: doi:10.1016/j.futures.2009.11.028

Sardar, Z. (2010). The Namesake: Futures; futures studies; futurology; futuristic; foresight-What's in a name? Futures, 42, 177-184. doi: doi: 10.1016/j.futures.2009.11.001

Schensul, J. J. (2009). Community, culture and sustainability in multilevel dynamic systems intervention science. American journal of community psychology, 43(3-4), 241-256. doi: 10.1007/s10464-009$9228-\mathrm{x}$ 
Schneider, F., Ledermann, T., Fry, P., \& Rist, S. (2010). Soil conservation in Swiss agriculture - Approaching abstract and symbolic meanings in farmers' life-worlds. Land Use Policy, 27, 332-339. doi: doi:10.1016/j.landusepol.2009.04.007

Schneider, F., \& Rist, S. (2013). Envisioning sustainable water futures in a transdisciplinary learning process: combining normative, explorative, and participatory scenario approaches. Sustainability Science, 119. doi: $10.1007 / \mathrm{s} 11625-013-0232-6$

Schneidewind, U., \& Jahn, T. (2012). Partner einer transformativen Wissenschaft. NaWis und Ecornet geben wissenschaftspolitische Impulse. GAIA - Ecological Perspectives for Science and Society, 21(3), 233235.

Schneidewind, U., \& Singer-Brodowski, M. (2013). Transformative Wissenschaft. Klimawandel im deutschen Wissenschafts- und Hochschulsystem. Weimar bei Marburg: metropolis.

Sen, A. (2009). The idea of Justice. London, UK: Allen Lane.

Smith, A., Voß, J.-P., \& Grin, J. (2010). Innovation studies and sustainability transitions: The allure of the multi-level perspective and its challenges. Research Policy, 39(4), 435-448. doi: http://dx.doi.org/10.1016/j.respol.2010.01.023

Spivak, G. C. (1988). Can the Subaltern speak? In C. Nelson \& I. Grossberg (Eds.), Marxism and the Interpretation of Culture (pp. 271-313). Urbana and Chicago, IL: University of Illinois Press.

State Secretariat for Education Research and Innovation. (2014). Promotion of education, research and innovation for 2013-2016 Retrieved March 24, 2014, from www.sbfi.admin.ch/org/01645/index.html?lang=en

Sterling, S. (2011). Transformative Learning and Sustainability: sketching the conceptual ground. Learning and Teaching in Higher Education(5), 17-33.

Stollberg, D. (2008). TZI und Hierarchie. Themenzentrierte Interaktion/TZI - Theme-Centered interaction/TCI, 22(2).

Tàbara, J. D., \& Chabay, I. (2013). Coupling Human Information and Knowledge Systems with socialecological systems change: Reframing research, education, and policy for sustainability. Environmental Science \& Policy, 28(0), 71-81. doi: http://dx.doi.org/10.1016/j.envsci.2012.11.005

Ulrich, P. (2008). Integrative Economic Ethics - Foundations of a Civilized Market Economy. Cambridge, UK: Cambridge University Press.

Ulrich, W. (1994). Can We Secure Future-Responsive Management Through Systems Thinking and Design? . Interface, 24(4), 26-37.

Ulrich, W. (2012a). Operational research and critical systems thinking-an integrated perspective. Part 1: OR as applied systems thinking. Journal of the Operational Research Society, 63, 1228-1247. doi: doi:10.1057/jors.2011.141

Ulrich, W. (2012b). Operational research and critical systems thinking-an integrated perspective. Part 2: OR as argumentative practice. Journal of the Operational Research Society, 63, 1307-1322. doi: doi:10.1057/jors.2011.145

van Egmond, N., \& de Vries, H. (2011). Sustainability: The search for the integral worldview. Futures, 43, 853-867. doi: doi:10.1016/j.futures.2011.05.027

van Gigch, J. P. (2006). Progress Achieving C. West Churchman's Epistemological Program. In J. van Gigch (Ed.), Wisdom, Knowledge and Management: A Critique and Analysis of Churchman's System Approach. (pp. 1-13). Heidelberg, Germany: Springer.

VISION RD4SD. from www.visionrd4sd.eu/start

Voss, J.-P., Bauknecht, D., \& Kemp, R. (2006). Reflexive governance for sustainable development. Cheltanham: Edward Elgar Publishing.

WBGU. (1997). World in Transition. The Research challenge. Annual Report 1996. Bremerhaven, Germany: Wissenschaftliche Beirat der Bundesregierung Globale Umweltveränderungen.

WBGU. (2011). World in Transition - A Social Contract for Sustainability. Berlin: Wissenschaftliche Beirat der Bundesregierung Globale Umweltveränderungen.

WBGU. (2012). Research and Education: Drivers of Transformation. from Wissenschaftlicher Beirat der Bundesregierung Globale Umweltveränderungen (WBGU)

Wetzel, D. (Ed.). (2012). Perspektiven der Aufklärung - Zwischen Mythos und Realität. München, Germany: Fink.

Wiesmann, U., Hurni, H., Ott, C., \& Zingerli, C. (2011). Combining the Concepts of Transdisciplinarity and Partnership in Research for Sustainable Development. In U. Wiesmann, H. Hurni \& with an international group of co-editors (Eds.), Research for Sustainable Development: Foundations, Experiences, and Perspectives (pp. 43-70). Bern, Switzerland: Geographica Bernensia.

Williams, L. D. A., \& Woodson, T. S. (2012). The Future of Innovation Studies in Less Economically Developed Countries. Minerva, 50(2), 221-237. doi: DOI 10.1007/s11024-012-9200-z 
Wooltorton, S., Palmer, M., \& Steele, F. (2011). A Process for Transition to Sustainability: Implementation. Australian Journal of Environmental Education, 27(1), 160-174. doi: http://dx.doi.org/10.1017/S081406260000015X

Wortel, E., \& Bosch, J. (2011). Strengthening moral competence: a 'train the trainer' course on military ethics. Journal of Military Ethics, 10(1), 17-35. doi: DOI:10.1080/15027570.2011.562372

Wuelser, G., Pohl, C., \& Hirsch Hadorn, G. (2012). Structuring complexity for tailoring research contributions to sustainable development: a framework. Sustainability Science, 7, 81-93.

Zingerli, C., Fry, P., Bachmann, F., Flury, M., Förster, R., Kläy, A., \& Küffer, C. (2009). Kommunikationskompetenz. Eine Bedingung für erfolgreichen Wissensaustausch. GAIA - Ecological Perspectives for Science and Society, 18(3), 264-266. 